\title{
INITIAL IDENTIFICATION OF MUDHARABAH SAVINGS MARKET SHARE IMPROVEMENT STRATEGIES IN INDONESIA
}

\author{
Putri Ramadhani Saragih*1, Jaenal Effendi**), and Imam Teguh Saptono $\left.{ }^{* * *}\right)$ \\ *) School of Business, Bogor Agricultural University \\ Jl. Raya Pajajaran, Bogor 16151 \\ ${ }^{* *}$ Department of Syariah Economics, Faculty of Economics and Management, Bogor Agricultural University \\ IPB Darmaga Campus, Bogor 16680 \\ ${ }^{* * *)}$ Global Wakaf Corp. ACT \\ Jl. TB Simatupang Road, South Jakarta 12560
}

\begin{abstract}
Sharia banking has been arising for 26 years in Indonesia. Its market share is still lower than $5 \%$. Study about sharia banking's market share is always an interesting observation. Mudharabah savings as one of the third party fund has a significant role to improve market share by low cost fund type. The objectives of this study are to analyze mudharabah savings elasticity, significant independent factor to it and initial market share improvement strategies. The methods used to combine vector error correction model (VECM) and business model canvas (BMC). This research concludes that conventional bank rates and sharia bank outlets have a relationship with mudharabah contract savings demand. Furthermore, mudharabah savings has a substitute relationship with conventional saving by negative cross elasticity. The results are combined with business model canvas (BMC) to describe mudharabah saving business model as a managerial action to explain initial strategies of mudharabah saving. BMC arranged by choosing conventional bank rates as value proposition focus and sharia bank outlets as key resources focus.
\end{abstract}

Keywords: demand elasticity, mudharabah savings, business model canvas (BMC), sharia banking, initial strategies

\begin{abstract}
Abstrak: Perbankan syariah telah hadir di Indonesia selama 26 tahun. Namun pangsa pasar bank syariah masih dibawah 5\%. Penelitian mengenai pangsa pasar perbankan syariah selalu menjadi penelitian yang menarik. Tabungan mudharabah merupakan salah satu dana pihak ketiga murah yang dapat meningkatkan pangsa pasar. Tujuan penelitian ini untuk menganalisa elastisitas permintaan dan faktor independen yang berpengaruh signifikan terhadap permintaan tabungan mudharabah serta menentukan strategi awal peningkatan pangsa pasar bank syariah. Metode yang digunakan adalah vector error correction model (VECM) and business model canvas (BMC). Penelitian ini menyimpulkan bahwa suku bunga tabungan konvensional dan jaringan bank syariah memiliki pengaruh terhadap permintaan tabungan mudharabah. Hubungan tabungan konvensional dengan tabungan mudharabah bersifat substitusi. Implikasi manajerial penelitian disajikan berdasarkan hasil penelitian dan analisa BMC sebagai inisiasi awal strategi tabungan mudharabah. BMC disusun melalui pemilihan variabel suku bunga bank konvensional sebagai fokus blok value proposition dan jaringan bank syariah sebagai fokus blok key resources.
\end{abstract}

Kata kunci: elastisitas permintaan, tabungan mudharabah, business model canvas (BMC), bank syariah, strategi awal

${ }^{1}$ Corresponding author:

Email: putri_3103@yahoo.co.id 


\section{INTRODUCTION}

The existence of Sharia banks in Indonesia has been going on for more than 26 years. During that period, sharia banks have been able to increase a prospective growth more than conventional ones. It proved by sharia banks asset growth was $20.3 \%$ than conventional bank was 9.4\% per position of 2016 (OJK, 2016). However, its growth rate cannot represent the success of sharia banks because it was not in line with its market share as $5 \%$. Sharia growth is still has moderate growth than conventional bank (Sumantri, 2014). The unsatisfactory growth rate can be seen in the data of market share average of the Third Party Fund (TPF) of sharia banks compared to conventional banks for the last seven years, which has been $<5 \%$ that is $4.59 \%$. TPF composition is mostly still in the form of deposits as much $59 \%$, savings $31 \%$ and obligation $10 \%$.

The composition of profit sharing contract savings is bigger than that of the deposit contract savings. Per position of 2016, the savings volume with a profit sharing agreement was 66 trillion rupiah and the saving with a deposit was IDR18 trillion (OJK, 2016). Profit sharing in the sharia bank savings is analogous to the savings product price. There are price and nonprice factors that influence demand of a product. Factor that influence demand (Yuniarti, 2016) are as follows: price of goods, other goods price, income rate, outlet (Maski, 2010) and maslahah. Al Ghifari et al. (2015) and Islamic Economics Assesment and Development Center of University of Islamic Indonesia (IEADC) UII (2015) performance measurement of a sharia bank can use maqashid index, one of whose elements is maslahah. The measurement is aimed at seeing the sharia bank performance based on its main goal. For this reason, in order that a sharia bank is able to optimize the development of its TPF supported with low cost fund such as savings, it is necessary to learn what factors influence the savings volume movement significantly. Those factors must be able to be researched further to find out the scale and direction of its influence on the savings volume. Savings account is an instrument that has an important role for the people as a security of excess asset during the prosperous time so that whenever they are broke, they are ready and have a saving fund Al-Hadist (2012) and Al-Qur'an (2015).

In order to reach the goal sharia banks with a market share of $>5 \%$, sharia banks must be able to generate TPF with a low cost fund composition. This improved fund of sharia bank can be influenced by many factors. Sukirno (2015), factors that influence savings demand in Indonesia are savings profit sharing rate, interest, number of sharia bank outlets and income rates. Data realization of mudharabah savings movement from 2010 to 2016 is refer to Table 1 .

During the last seven years period, mudharabah contract savings demand has been increasing, but saving profit sharing of mudharabah experiences decreasing fluctuations in some years. The conventional bank interest experiences an increase in some years while sharia bank network keeps decreasing from 2013 to 2016 due to the efficiency issue by closing some existing outlets.

There are some differences between theory and its volume realization of mudharabah savings so that it is necessary to learn more the demand elasticity of mudharabah savings. Elasticity is a universal measurement standard to explain changes, that is by using elasticity concept (Nicholson, 1994). Specifically for maslahah variable, it can be explained using the financial ratio (Afrinaldi, 2013).

Explanation for others variables such as interest. Interest is one of the variables that are often analyzed on savings demand. In sharia banks, interest is like a profit sharing level. The profit sharing level influences positively on profit sharing savings of sharia banks, while interest of conventional banks influences negatively on sharia bank saving demand (Kasri and Kasim, 2009).

The relationship between price and demand is substitutive or complementary. According to (Grace et al. 2014) in the research concerning cross elasticity of e-cigarette, it is estimated to be 0.6 , so partially it is possible to substitute it with a regular cigarette. In this simulation, regular cigarette demand decreases $42.8 \%$ if it is available; however, if the e-cigarette price increases two times of the market price, $50.2 \%$ cigarette users will stop smoking e-cigarette. The comparison of substitute relationship between cigarette and e-cigarette was used because the analogy as addicted product similar with conventional bank with sharia bank as substitute. If the mudharabah saving product has a substitutive relationship with the conventional savings, the relationship will be the opposite to the interest rate increase of the conventional savings (Chen and Jin, 2014). There is another factor, i.e. income, which has an influence on demand for goods. Permanent income 
has income elasticity as much as $0.375-0.447$ and the present income elasticity becomes smaller, that is $0.278-0.288$.

Another factor that can be analyzed to determine sharia bank elasticity is by maqashid sharia in the form of maslahah. Maqashid sharia can be used as one of the performance indicators of sharia bank to measure the benefit level of a financial institution (Syofyan, 2016).

To combine the research results to become a business strategy, it is necessary to use a tool of business model canvas (BMC). Through BMC it can be identified what factors are able to be developed by BMC block so that the entity can find out what becomes the focus and the priority (Wicaksono et al. 2017).

The results of elasticity will be elaborated using BMC methods by mapping it into business model canvas (BMC) block. BMC is one of the business efforts to visualize the value and strategy of organization in one business canvas unit (Osterwalder and Pigneur, 2015). The results of mapping are then developed into the whole cell block of BMC. BMC block expresses the initiation of mudharabah BMC savings model so that in the next research it can be used as a reference for making general mudharabah savings strategies for sharia banks.

Previous researches those are (Kasri and Kasim, 2009), (Chen and Jin, 2014), and (Grace et al. 2014) only discussed conventional factors that influenced savings. About sharia factor like maqashid sharia is maslahah, that researched by (Afrinaldi, 2013), (Al-Ghifari, 2015) dan (Syofyan, 2016) only discussed about relationship maslahah with bankwide performance. At strategy implication part, (Wicaksono et al. 2017) using BMC with SWOT analysis.

The novelty of this research is about combining conventional and sharia factors to mudharabah saving demand and elasticity. Furthermore, the research also discusses it until elasticity level that happens in mudharabah savings. The research results are discussed comprehensively by comparing the realization data on mudharabah saving demand. The managerial implications of the research are more comprehensive since it combines the research results with interviewing the experts and questionnaires using business model canvas (BMC) block.
The scope oh this research discussed about short term liabilities aspect of sharia bank that is mudharabah saving. The analysis result about independent factors of mudharabah saving demand will be described by Business Model Canvas BMC). That saving is analyzed based on its demand elasticity with independent factors profit sharing, conventional interest rate, income, sharia outlets and maslahah. The result described by Business Model Canvas (BMC).

Based on the research background, the objectives of the research are as follows: to analyze demand elasticity of mudharabah savings in sharia banks; To analyze the influences of independent factors (mudharabah savings profit sharing, interest rate, income level, sharia bank network and maslahah) on mudharabah contract savings demand in sharia banks; To formulate the initialearly strategies to accelerate market share from the TPF viewpoint of good mudharabah savings for sharia banks based on the results of elasticity analysis and business model canvas analysis.

\section{METHODS}

Location research in Jakarta. This research starting at March-November2017. This research uses secondary data of report and metadata from the Bank of Indonesia (BI), the Financial Services Authority (OJK) and Statistics Bureau (BPS). This research used time series data. The type of data collected uses statistical data source issued quarterly. This research also used questionnaires and responses from an in-depth interview for BMC analysis.Other data collected in this research are questionnaires of BMC analysis and responses from in-depth interview.

The technique for collecting data was report documentation and sharia bank statistical data. The report and the statistical data are documented according to position years. Report and statistical data wereare tabulated and then processed. The results of BMC questionnaires and in-depth interview will be tabulated and then recapitulated as observatory results.

The secondary data research analysis uses the VECM (Vector Error Correction Model) method. VECM is an analyzing tool of multiple regressions that can analyze dependent as well as independent variables. This research was used VECM to analysis regression and conitegration data (Brandt and Williams, 2007). VECM 
is used for data of time series so that every variable requirement must comply with stationary requirement (Nachrowi and Usman, 2006). This research using VECM for different aspect and tools from previous research that using least square method. The stages of analysis using VECM are as follows:

\section{Data Stationary Test}

Stationary test is carried out to find out data distribution or time series data. The test method uses ADF (Augmented Dicky Fuller) test with the real stage 1\%, $5 \%$ or $10 \%$. The $\mathrm{t}-\mathrm{ADF}$ test result must be smaller than the MacKinnon critical value. This indicates that the data is stationary (there is a unit root).

\section{Co-integration Test}

Co-integration test is aimed at finding the long-term relationship between variables. The value compared is probability value that must be smaller than the real stage. If the indication is fulfilled, it can be said that the station air regression equation is in the right level.

\section{VECM Modeling}

VECM model is analyzed with a long-term model prediction using Engle-Granger Co integration method. This prediction analyzed by comparing the projection between dependent variable and independent variables. Further prediction is through the projection of short-term influence between dependent variables and independent variables . The requirement for short-term model value to be fulfilled (ECM) is the coefficient ECT value (-1), meaning $-1<\mathrm{a}<0$ and significant (prob. $<0.10$ ).

\section{Classic Assumption Test}

Classic Assumption Test is a statistical test effort in regression methods so that the results can ensure if the model used can meet the BLUE (Best Linear Unbiased Estimator) requirement. The test consists of normality test, autocorrelation test, heteroscedascity test, and multicolinearity test.

Based on the analyzing tool used, that is multiple regression analysis, the variables used in this research consist of independents and dependent variables. The dependent variable in this research is savings demand $(\mathrm{Y})$, while the independent variables are the profit sharing of sharia bank savings (X1), interest rate of conventional bank savings (X2), people's income rate (X3), sharia bank network (X4), and maslahah (X5). The framework of thought in this study is presented in Figure 1.

The hypothesis or something that is going to be proved in this research is related to factors that influence mudharabah savings demand. The research hypothesis is as follows:

H1 : There is an influence of profit sharing on mudharabah saving demand.

H2 : There is an influence of conventional saving interest on mudharabah saving demand.

H3 : There is an influence of people's income on mudharabah saving demand.

H4 : There is an influence of sharia bank network on mudharabah saving demand.

H5 : There is an influence of maslahah on mudhabarabah saving demand.

\section{RESULTS}

Data of mudharabah contract savings demand that have been analyzed in this research using VECM methods produce output that there are two independent variables that influence mudharabah contract savings demand. The variables are conventional bank savings interest (X2) and sharia bank network (X4). Variable X2 and $\mathrm{X} 4$ have influence on mudharabah contract savings demand on the long-term model only.

The result of long term analysis The analyzing result of long-term model is obtained through several stages of VECM analysis. The stationary test on the second difference says that the data are of stationary nature in each variable with the real stage $1 \%, 5 \%$ and $10 \%$. The probability value of each variable is smaller than the real stage.

The next analyzing step is testing the residue of regression equation to find out the co-integration relationship or co-integration test. The ADF t-statistic value is smaller than the MacKinnon critical value on the real stage of $1 \%, 5 \%$ and $10 \%$. This shows that the stationary regression equation residue is at the right level. 


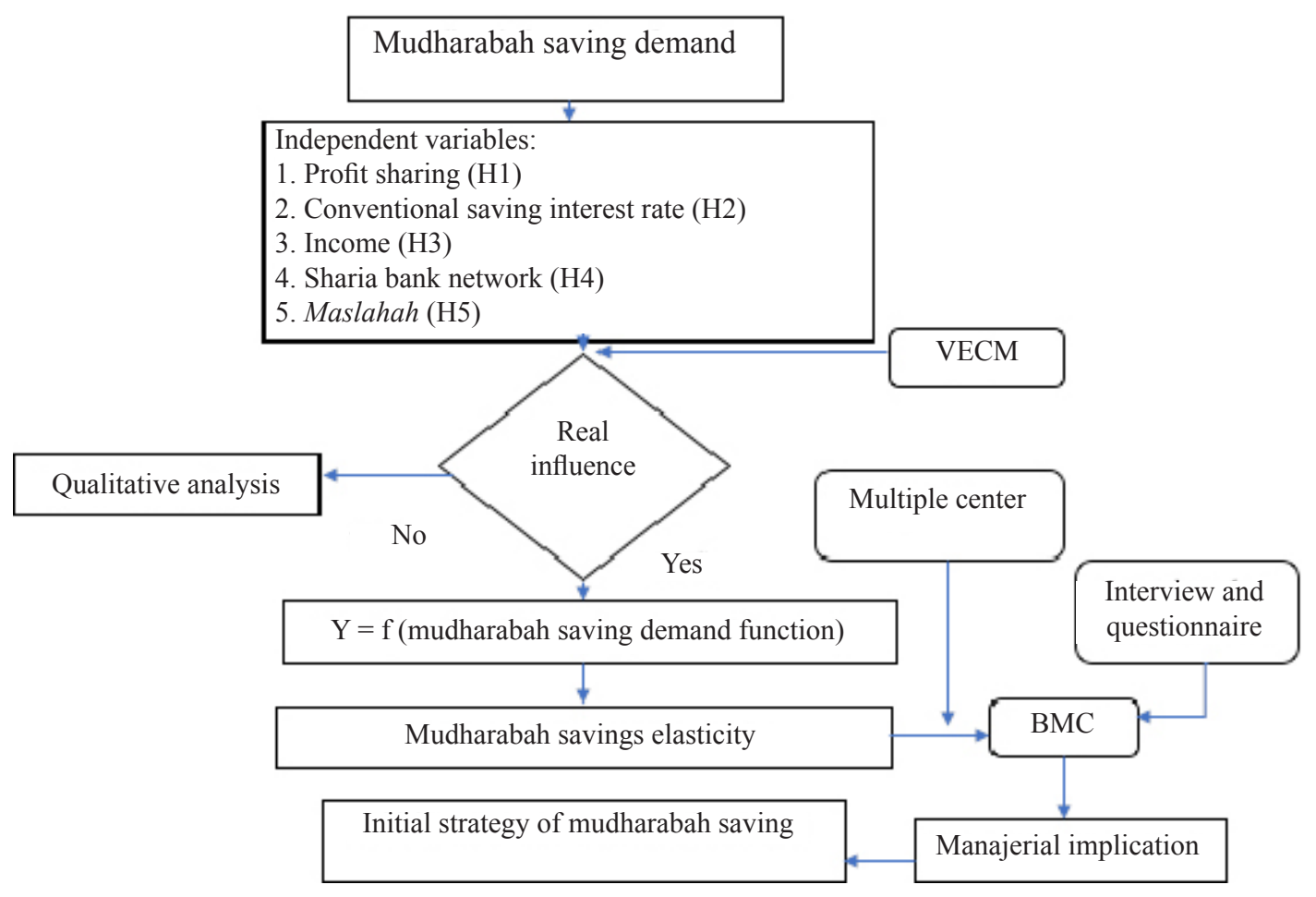

Figure 1. Research framework

The long-term model can be determined because the variables have been stationary and have co-integration relationship within variables. The long-term model has been identified using Engle-Granger Co integration method. The real influence can be identified according to the probability value compared with the real stage $10 \%$. The interest rate variable of conventional savings (X2) with a prob.value 0.0667 and sharia bank network (X4) is 0.0000 so that it has a significant influence on mudharabah contract savings demand.

According to the processed results of long-term model data, it is found out that the R-squared value is $94.27 \%$. The value explains that the long-term model can explain the variety of mudharabah contract savings demand as much as $94.27 \%$ so that the rest (5.73\%) is explained by another factor outside model. The function of mudharabah contract savings demand based on processed data is as follows:

$$
\mathrm{Y}=-192498.6-718958.9 \mathrm{X} 2+27.5143 \mathrm{X} 4+\mathrm{e}
$$

The next step is classic assumption test to test the normality, autocorrelation, heteroscedascity and multicolinearity. All these classic assumption test series need to be carried out because if it proves to have no test indicator, the research model can become a reference for the best estimation model. All the classic test assumptions in the research have been met.

\section{Demand of Mudharabah Contract Savings}

The conventional bank interest rate (X2) has a negative significant influence (the opposite direction) on mudharabah contract savings demand (Y). Statistically, the prob. $\mathrm{X} 2$ value is smaller than the real stage $10 \%$ so that the Ho is rejected. If X2 experiences an increase, it will have a potential to decrease mudharabah contract savings demand. The real condition can be seen between the data of mudharabah contract savings growth from period Q1 to Q4 in 2013 as much as IDR2,209 billion compared to period Q1 to Q4 in 2014 as much as IDR1,104 billion. The average growth of mudharabah contract savings decreases. The realization of variable $\mathrm{X} 2$ growth during the same period experiences an increase that is $0.03 \%$ to become $0.10 \%$. The different trend of growth is explained in Figure 2.

Conventional bank as a bank that has a more fluctuative pricing system because of its policy to determine interest rate is very much influenced by external factors that are related to interest rate. The interest rate growth that is relatively low during the 2013 quarters is influenced by the global economic condition and policy. The global economic condition especially focuses on the USA, as one of the countries that gives a big economic fluctuative impact on Indonesia. In that year it experienced crises. The USA anticipated the crises by monetary policy that is called Quantitative Easing (QE), i.e. a decrease of interest rate (Indonesia Banking Report, 2013). 
Sharia bank network variable (X4) with a prob. value as much as 0.0000 or smaller than the real stage makes the Ho rejected. Variable X4 influences significantly the mudharabah contract savings demand. The influence is positive with a coef. Value as much as 27.51438 so if the number of sharia bank office network increases, it will increase the demand for mudhararabah contract savings such as illustrated in Figure 3.

The condition of mudharabah savings demand in 2013 compared to that in 2014 is in line with the Al-Quran translation of Surat (epistle) Yusuf verse 47-48 with the suggestion from Prophet Yusuf As. That during the harvest time it would be better to save than to consume. This indicates that sharia bank condition in 2014 was worst than 2013 so it is better for sharia bank to consume less than usual in 2013 (Figure 4). The rest of consume should be saved for guarantee inventory in 2014This indicates that the situation in 2013 with the growth rate of mudharabah savings bigger than the following year, it is better for sharia bank to consume less than usual, that is by distributing credit that is not so aggressive. This can be seen in Figure 4. There was a decrease of growth rate in mudharabah savings, expenses, and net profit of sharia bank in 2013 compared to 2014.

The number of sharia bank office network are still limited compared to conventional bank. The research results Qomariyah (2014) and Adi et al. (2016) was show ed that one of the important factors that make a customer to open a savings account is an easy access such as a branch office network of a bank. The comparison of the number of network between sharia bank and conventional bank is given in Figure 5.

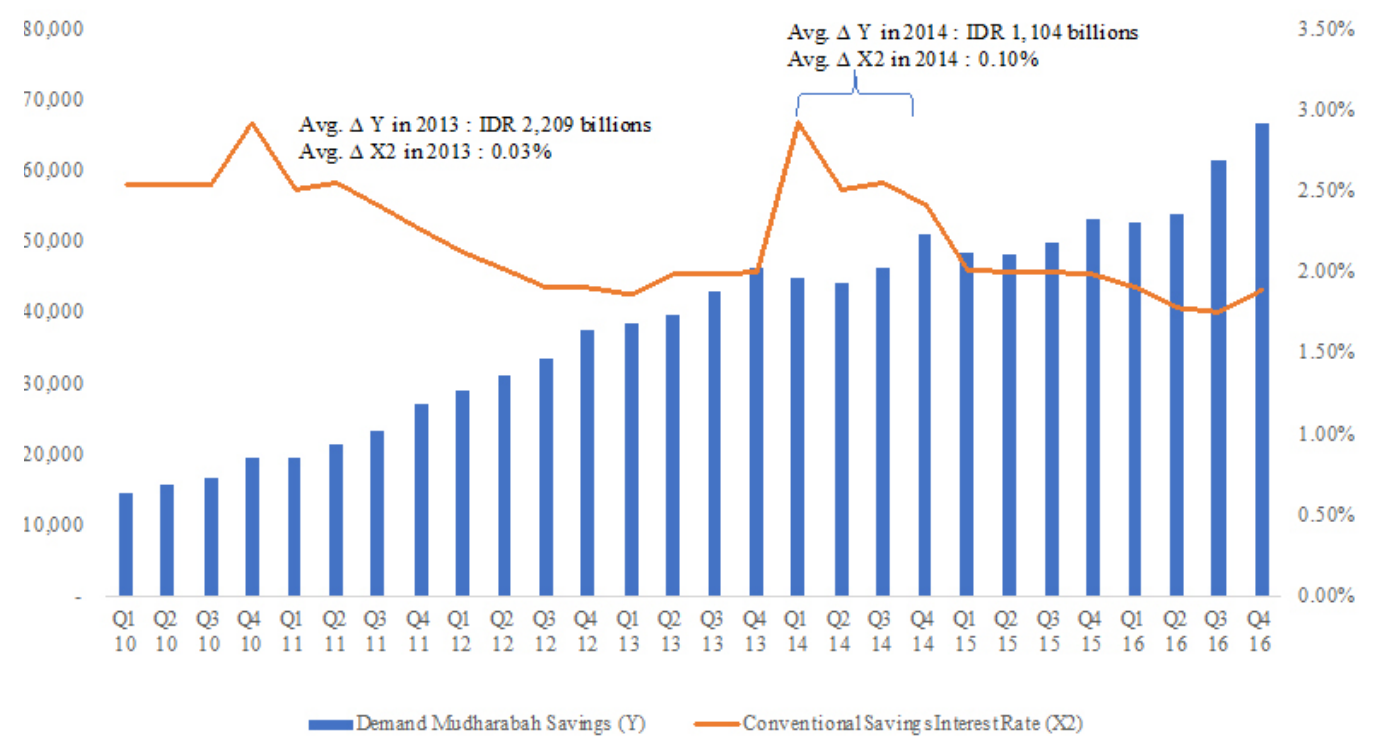

Figure 2. Comparison of mudharabah saving and rate of conventional bank $\mathrm{Y}$ and $\mathrm{X} 2$ growth

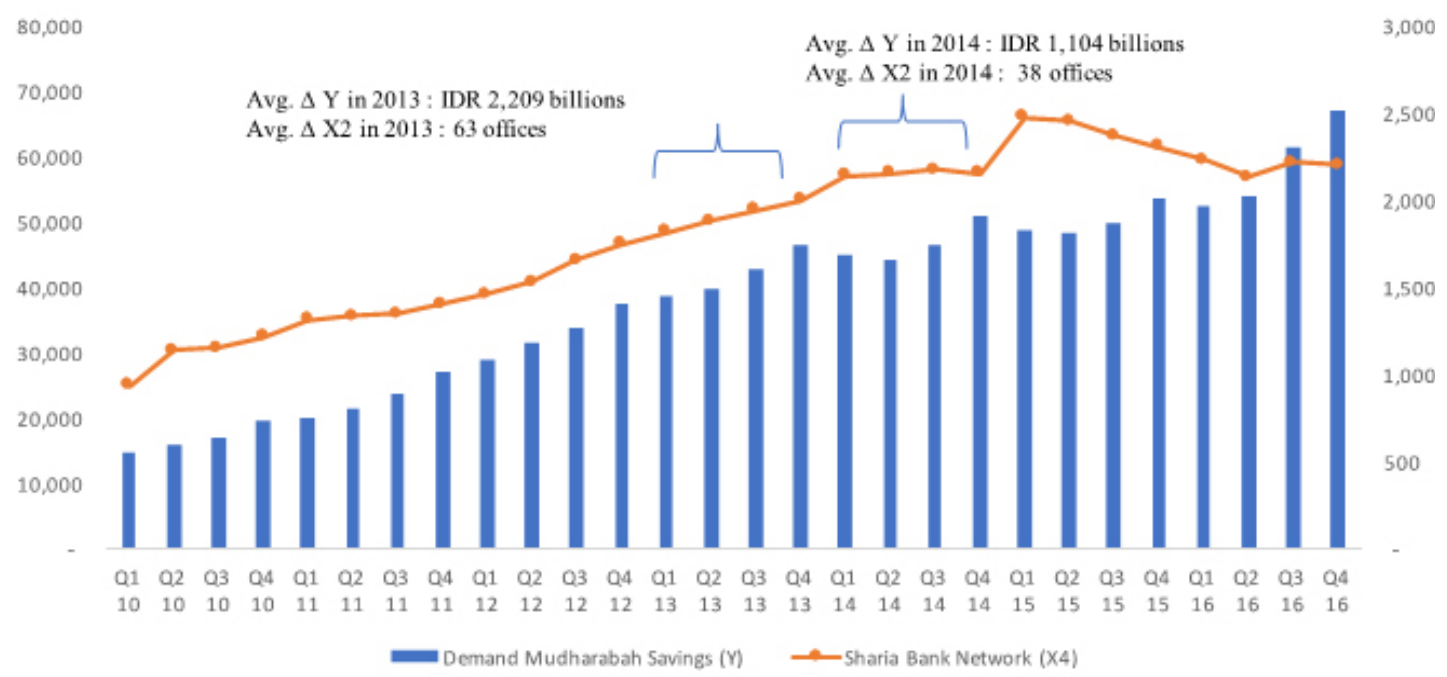

Figure 3. Comparison of variable mudharabah saving and sharia bank network $\mathrm{Y}$ and $\mathrm{X} 4$ growth 


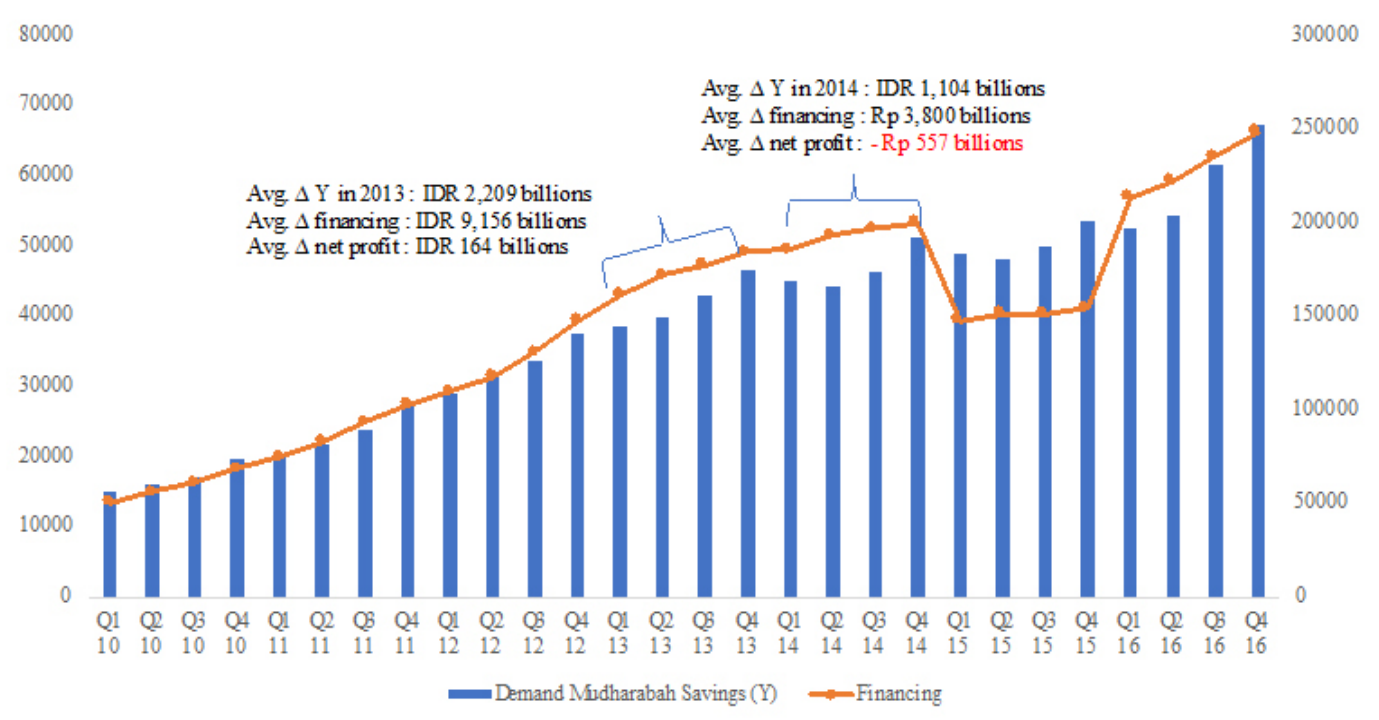

Figure 4. Comparison of mudharabah savings demand and expenses

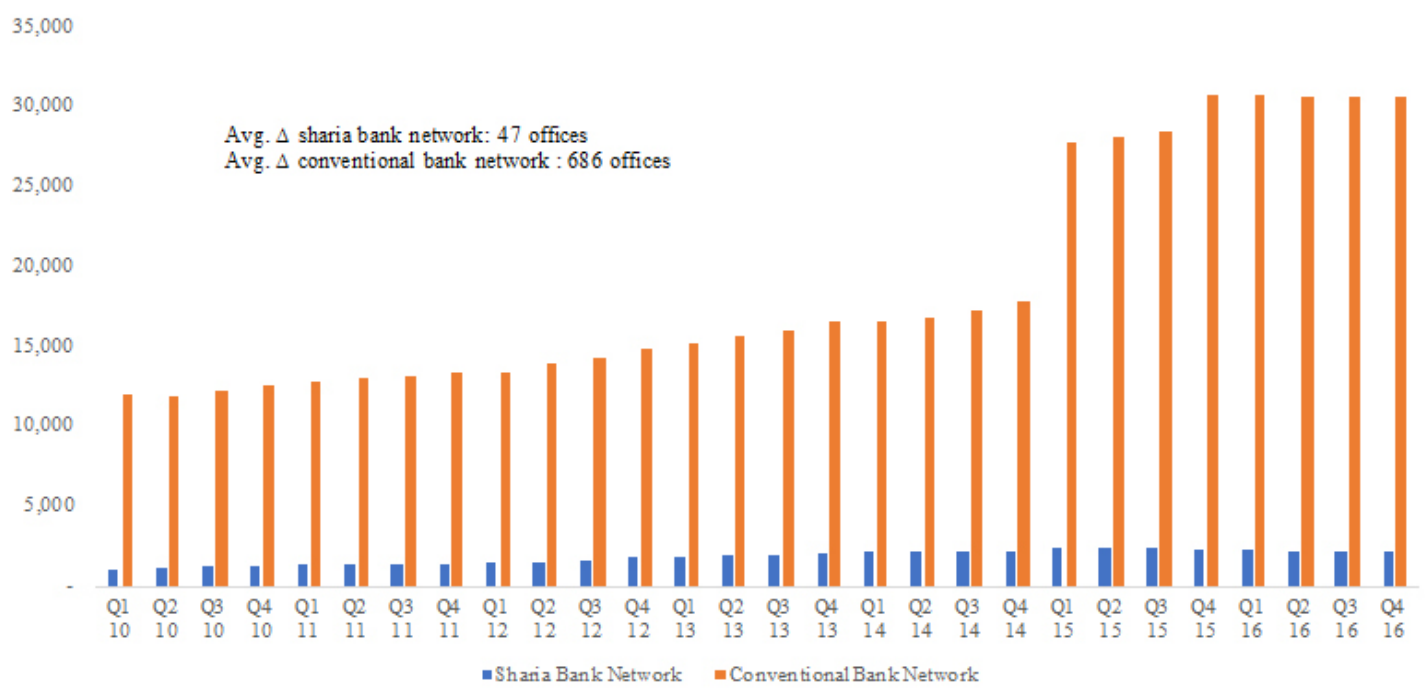

Figure 5. Comparison of number of network between sharia bank and conventional bank

The development of bank that has entered a new digital stage requires each bank to develop faster in its information and technology (IT) system and banking access from anywhere. In line with Shabirah and Aldianto (2014) it says that the existence of branchless banking is a form of bank cooperation with the third party so that the customers will get easier access to have banking services without having to be present in the bank. It is better if the office network of a bank is not limited to physical condition of the office but also to branchless banking that is created by the bank. This can minimize constraints from the financial institution for the people's access to get the banking services (Sarah, 2016).
The profit sharing variable (X1) does not have a significant influence on mudharabah contract savings demand because of the customers' motivation in opening an account. Profit sharing is not the main factor a customer opens an account of mudharabah contract savings. The main motivation for a customer to open an account is because of the sharia contract and value of the savings product (Irviana et al. 2008; Hendra, 2008). Customers will consider another factor that they will get from a conventional bank such as an easiness and security. Profit sharing calculation is the third factor that will be considered by the customers in opening a mudharabah savings account (Herawati, 2012). Based on Hapidah et al. (2017), customer saving decision defined by three main factors that personal factor, social factor and information. Furthermore, every sharia 
segment has different mindset. Sharia banking segment are sharia loyal, floating mass and conventional loyal with the most number segment is floating mass (Gafur, 2014). So sharia bank have to improve service quality, prize or product variance (Silviana and Putra, 2017). But perception is one of important aspect that relate to saving decision (Adawiyah, 2010). Customer will choose sharia bank, if sharia bank has prime and excellent service (Daulay, 2010).

Income variable (X3) does not have a significant influence on mudharabah contract savings demand (Y). Income generally has a positive correlation with savings demand. If someone's income increases, there is a tendency for the person to increase consumption and the rest will be put into a saving with a proportion more than previously (Nizar, 2007). In this research saving interest rate (X2) is significant but has a negative value. It indicates that mudharabah contract savings is a substitution of conventional bank. Therefore, there is a possibility that increasing of income can increase conventional savings than sharia savings. Customer with rising income prefer to better service banks.

The research uses a non-conventional factor that influences demand for mudharabah contract savings, that is maslahah (X5). The results show that maslahah does not have a significant influence on the demand of mudharabah contract savings. In practice, maslahah is like another thing that motivates someone to open mudharabah contract savings. The performance measurement of sharia bank in terms of increasing prosperity of operational activities can be measured using maslahah ratios, that is probability, profitability, interest distribution, and real sector investment (Al Ghifari et al. 2015). However, if it is seen from the realization data of cost distribution that has been carried out, sharia bank can be regarded as having a contribution to economic development or maslahah through its partiality towards Mid-Small Business sector (UKM). The sector contribution was as much as $52 \%$ of the total cost value in 2010 until 2016.

\section{Elasticity Analysis}

Based on the processed data of the research, it is said that that has a significant influence on the demand for mudharabah contract savings is only the conventional bank interest rate (X2) and the number of sharia bank network (X4). Thus, the elasticity analysis that can be carried out is only for cross elasticity on variable $\mathrm{X} 2$.
The coef. X2 is -718958.9 , which means that every time there is an interest decline in the conventional bank as much as $1 \%$ unit, there is a potential to increase demand for mudharabah contract savings as much as IDR718 trillion.

Further coefficient analysis is concerning the change in the number of sharia bank office networking. Based on the results of the research, sharia bank networking (X4) has a coef. value 27.51438. If a sharia bank adds one sharia bank office in its operational activity, there is a potential to increase the demand for mudharabah contract savings as much as IDR27 billion. Based on coefficient analysis of variable $\mathrm{X} 2$ and $\mathrm{X} 4$, the elasticity value of $\mathrm{X} 2$ is $0.41(\mathrm{e}<1)$ and $\mathrm{X} 4$ is $1.29(\mathrm{e}>1)$.

\section{Managerial Implication}

The results of time series data analysis on some independent variables with VECM methods produce two variables that have significant influence on the demand of mudharabah savings, that is conventional bank interest rate (X20 and sharia bank networking(X4). The business innovation mapping in this research uses multiple centers (Osterwalder and Pigneur, 2015) X2 in the value proposition block and $\mathrm{X} 4$ in key resources block with BMC design in Figure 6. This BMC is an initial strategies of mudharabah savings.

\section{CONCLUSIONS AND RECOMMENDATIONS}

\section{Conclusions}

Based on the combining of VECM results, depth interview and BMC analysis, there are conclusion of this research: Sharia bank mudharabah savings product has only one elasticity value, namely cross elasticity. Cross elasticity expresses that the relationship between mudharabah savings and conventional bank savings is substitutive. If there is a change in price (interest rate) conventional bank savings, mudharabah bank savings demand will be the opposite. Factors that influence the demand of sharia bank mudharabah savings are conventional bank interest rate and sharia bank network. Conventional bank interest rate has the opposite relation to mudharabah savings demand while sharia bank network has a smilar relation. The strategy to increase market share according to the research results is described through business model canvas (BMC) with 9 mutual relationship blocks. Based on that 
BMC concluded that the focus of mudharabah savings development are value proposition and key resources aspect. As an initial strategies, this BMC can be guide for the next level of research about mudharabah saving more specific.

\section{Recommendations}

Further research can be conducted more deeply concerning elasticity analysis of other TPF products, namely the current account. The research on the current account should be carried out through comparative study with non-bank products. Policy determination for banking stakeholders related to mudharabah savings can use this research BMC, keeping in line with the size of bank business managed. To use BMC model, stakeholder also considerate the other aspect like customer demography and profile.Besides, demography and profile of sharia bank customers become the main factor that determines the customer segments. The strategy of increasing market share in the next research needs to be combined with SWOT analysis so that experts can consider more comprehensively.

\section{REFERENCES}

Adawiyah WR. 2010. Pertimbangan, pengetahuan, dan sikap konsumen individu terhadap bank syariah. Jurnal Ekonomi Pembangunan 11(2): 191-201. https://doi.org/10.23917/jep.v11i2.324.

Adi RN, Ferdinand AT, Soesanto H. 2016. Studi tentang product advantage, service quality dan bank location terhadap saving decision pada bank syariah: studi pada BSM dan Bank Muamalat kota Semarang. Jurnal Sains Pemasaran Indonesia 15(2): 130-140.

Afrinaldi. 2013. Analisa kinerja bank syariah Indonesia ditinjau dari maqasid syariah: pendekatan syariah maqashid indeks dan profibilitas bank syariah. Jurnal Islamic Economic \& Finance (IEF) Universitas Trisakti.

Al Ghifari M, Lukman LH, Yani EA. 2015. Analisa kinerja perbankan syariah di indonesia dan malaysia dengan pendekatan maqasid syariah indeks. Jurnal Ekonomi dan Perbankan Syariah

\begin{tabular}{|c|c|c|c|c|}
\hline \multirow[t]{2}{*}{$\begin{array}{l}\text { Key partners } \\
\text { 1.IT company } \\
\text { 2. Community } \\
\text { 3. Sharia business } \\
\text { 4. Company } \\
\text { investment } \\
\text { manager }\end{array}$} & $\begin{array}{l}\text { Key activities } \\
\text { 1. e-channel service } \\
\text { development } \\
\text { 2. Opening online } \\
\text { account } \\
\text { 3. Corporate } \\
\text { networking } \\
\text { 4. Easiness to open } \\
\text { an account }\end{array}$ & \multirow[t]{2}{*}{$\begin{array}{l}\text { Value Propositions } \\
\text { 1. Fiture and facilities } \\
\text { 2. Clear product contract } \\
\text { 3. Ease to access }\end{array}$} & \begin{tabular}{|l|}
\multicolumn{1}{c|}{$\begin{array}{c}\text { Customer } \\
\quad \text { relationships }\end{array}$} \\
1.Loyalty program \\
2. E-channel service \\
3. Community
\end{tabular} & \multirow[t]{2}{*}{\begin{tabular}{|l|}
\multicolumn{1}{|c|}{ Customer segments } \\
1. Rational customers \\
2. Sharia loyal customers \\
3. Non-individual customers
\end{tabular}} \\
\hline & $\begin{array}{l}\text { Key resources } \\
\text { 1.e-channel } \\
\text { technology } \\
\text { 2. Workers } \\
\text { 3. Office network }\end{array}$ & & \begin{tabular}{l}
\multicolumn{1}{c|}{ Channels } \\
1. Viral social media \\
2. Website \\
3. Seller \\
4. Digital banking \\
$\quad$ (B2B)
\end{tabular} & \\
\hline \multicolumn{3}{|c|}{$\begin{array}{l}\text { Cost Structure } \\
\text { 1.IT development } \\
\text { 2. Additional office network } \\
\text { 3. Labour } \\
\text { 4. Marketing and promotion }\end{array}$} & \multicolumn{2}{|c|}{$\begin{array}{l}\text { Revenue Streams } \\
\text { 1.Profit sharing income } \\
\text { 2. Service cost income } \\
\text { 3. Ujroh income } \\
\text { 4. Transaction cost income }\end{array}$} \\
\hline
\end{tabular}

Figure 6 . Initial mudharabah savings strategy by business model canvas mudharabah savings 
3(2): 47-66.

Al-Hadist. 2012. Kitab Shahih Al-Bukhari dan Muslim. Jakarta: Perpustakaan Nasional RI.

Al-Qur'an. Al-Qur'an Medina dengan Terjemah dan Materi tentang Akhlak Mulia. Jakarta: PT Madina Raihan Makmur.

Brandt PT, Williams JT. 2007. Multiple Time Series Model. America: Sage Publication

Chen J, Jin M. 2014. Income elasticity of housing in China: micro data evidence from Shanghai. Journal of Contemporary China 23(85):68-84. https://doi.org/10.1080/10670564.2013.809979.

Daulay R. 2010. Analisi pelayanan dan bagi hasil terhadpa keputusan menabung nasabah pada bank syariah di Kota Medan. Jurnal Manajemen dan Bisnis 12(1):1-15. https://doi.org/10.30596/ jrab.v12i1.91.

Gafur A. 2014. Analisis faktor yang mempengaruhi perilaku pedagang etnik Tionghoa dalam memanfaatkan jasa bank syariah. Jurnal Studi Ekonomi At Taradhi 5(2).

Grace RC, Kivell BM, Laugesen M. 2015. Estimating cross price elasticity of e-cigarettes using a simulated demand procedure. Nicotine \& Tobacco Research 17(5):592-598. https://doi. org/10.1093/ntr/ntu268.

Hapidah N, Zukhri A. Sujana IN. 2017. Pengaruh personal, faktor sosial dan informasi terhadap intensi menabung di bank syariah pada PT Bank Syariah Mandiri cabang Buleleng tahun 2016. Ejournal Jurusan Pendidikan Ekonomi 9(1).

Hendra. 2008. Faktor-faktor yang mempengaruhi loyalitas bank syariah [thesis]. Depok: UI.

Herawati. 2012. Kepuasan nasabah terhadpa bank dan dana pihak ketigas Unit Usaha Syariah BNI. Jurnal Organisasi dan Manajemen 8(1): 32-49.

Irviana RRK, Nurmalina R, Suroso AI. 2008. Analisis segmen pasar dan perilaku nasabah terhadap bank syariah di wilayah DKI Jakarta. Jurnal Manajemen dan Agribisnis 5(2): 87-97.

Kasri SA, Kasim S. 2009. Emperical determinant of saving in islamic banks: evidence from Indonesia. JKAU: Islamic Economics 22(2): 181-201.

Maski G. 2010. Analisa keputusan nasabah menabung: pendekatan komponen dan model logistik studi pada bank syariah di Malang. Journal of Indonesian Applied Economics 4(1): 43-57. https://doi.org/10.21776/ub.jiae.2010.004.01.4.

Nachrowi ND, Usman H. 2006. Pendekatan Populer dan Praktis Ekonometrika untuk Analisis Ekonomi dan Keuangan. Jakarta: Lembaga Penerbit FE UI.

Nicholson W. 1994. Teori Ekonomi Mikro: Prinsip Dasar dan Pengembangannya. Jakarta: PT Rajagrafindo Persada.

Nizar MA. 2007. Effect return and interest rates on saving deposit syariah and conventional bank in Indonesia. Kajian Ekonomi dan Keuangan 11(2):121-131.

Osterwalder A, Pigneur Y. 2015. Business Model Generation. Jakarta: PT Elex Media Computindo.

Qomariyah N. 2011. Faktor-faktor yang mempengaruhi keputusan konsumen menabung di bank syariah: studi kasus di BSM cabang Jember. Jurnal Ekonomi Akuntansi dan Manajemen 10(1):3042.

Sarah H. 2016. Dampak branchless banking terhadap kinerja keuangan PT Bank Muamalat Indonesia Tbk. Jurnal Al Muzara'ah 3(2): 136-157. https:// doi.org/10.29244/jam.3.2.136-157.

Shabirah I, Aldianto L. 2014. The suitable model of branchless banking implementation in Indonesia. Journal of Business and Management 3(6): 633645.

Sukirno S. 2015. Mikroekonomi Teori Pengantar. Ed ke-3. Jakarta: PT Rajagrafindo Persada.

Sumantri BA. Pengembangan kapasitas institusi perbankan syariah dalampenyediaaninfrastruktur jaringan, SDM dan produk. Jurnal Eksyar 1(1): $1-17$.

Wicaksono AA, Syarief R, Suparno O. 2017. Business model in electricity industry using business model canvas approach : the case of PT XYZ. Indonesian Journal Business and Entrepreneurship 3(1):5263. http://dx.doi.org/10.17358/ijbe.3.1.52

Yuniarti VS. 2016. Ekonomi Mikro Syariah. Bandung: CV Pustaka Setia. 